\title{
Artur Seweryn, Teologia męczeństwa w przepowiadaniu św. Augustyna, Kraków 2011, 290 s.
}

Do istoty Kościoła, rozstrzygającej o jego „być” lub „nie być”, należy głoszenie słowa Bożego. „Kościół z natury jest misyjny, ponieważ bierze początek z misji Syna i misji Ducha Świętego, zgodnie z zamysłem Boga Ojca" (Ad gentes, 2). Ujawnienie tej misyjnej natury dokonuje się przez głoszenie słowa Bożego i sprawowanie sakramentów. W każdej epoce jednak posługa Kościoła znajduje przeciwników i natrafia na opór, a głosiciele słowa Bożego są prześladowani, a nawet pozbawiani życia, stając się męczennikami prawdy. Jak zauważa Katechizm Kościoła katolickiego, „męczeństwo jest najwyższym świadectwem złożonym prawdzie wiary; oznacza ono świadectwo aż do śmierci. Męczennik daje świadectwo Chrystusowi, który umarł i zmartwychwstał, z którym jest zjednoczony przez miłość. Daje świadectwo prawdzie wiary i nauki chrześcijańskiej. Ponosi śmierć w wyniku użycia wobec niego siły" (KKK 2473). Nic więc dziwnego, że Kościół z największą troską dokumentuje przez wieki świadectwa wiary złożone przez męczenników. Są to świadectwa tym cenniejsze, że zostały „zapisane krwawymi literami” (KKK 2474). Pogłębioną refleksję nad nimi podjął św. Augustyn, a jego teologia męczeństwa stała się przedmiotem naukowych badań ks. doktora Artura Seweryna, który przedstawił je w książce Teologia męczeństwa w przepowiadaniu św. Augustyna.

Autor publikacji jest pochodzącym z Olkusza prezbiterem diecezji sosnowieckiej.
W 1994 roku uzyskał magisterium z teologii na podstawie pracy Celibat kapłańskijako dar Boży. Recenzowana książka została przedstawiona jako rozprawa doktorska i obroniona na Uniwersytecie Papieskim Jana Pawła II w Krakowie w 2010 roku. W wydaniu drukiem liczy ona 290 stron.

Książka zawiera pięć rozdziałów (s. 11265), poprzedzonych słowem wstępnym autora (s. 5-9), a ponadto wykaz skrótów (s. 275277), bibliografię (s. 279-290) i zakończenie (s. 267-273). W aneksie ks. Seweryn zamieścił oryginalny tekst łaciński wybranych mów św. Augustyna oraz ich autorski przekład na język polski. W aneksie znalazły się zarówno całe wybrane mowy św. Augustyna, jak też fragmenty innych jego mów o tematyce martyrologicznej. Warto zauważyć, że większość z tych tekstów została po raz pierwszy przetłumaczona z oryginału łacińskiego na język polski. To jedna z zasług Artura Seweryna. Inną jest niezmiernie interesujące omówienie tematyki męczeństwa w przepowiadaniu najsławniejszego biskupa Hippony.

Treść publikacji odpowiada jej tytułowi, precyzyjnie wyjaśnionemu we wstępie. Autor pokazał bogactwo rozumienia terminu „męczeństwo" w różnych epokach historycznych. Wyróżnił męczeństwo czerwone - zdobyte za cenę życia; białe, czyli dziewictwo, szare - osiągane przez pokutę i zielone - zdobyte przez ofiarną posługę misyjną.

W strukturze książki uwidoczniona została troska autora o zachowanie proporcji 
poszczególnych rozdziałów. Pierwsze cztery mają podobną objętość. Ostatni natomiast, piąty, jest wyraźnie krótszy od pozostałych, co jest usprawiedliwione jego treścią. Dotyczy bowiem formalnej strony omawianego zagadnienia. W rozdziale pierwszym, wprowadzającym w całość rozważań, przedstawiony został religijny kontekst przepowiadania św. Augustyna na temat męczeństwa. Zaprezentowane zostały także dzieła martyrologiczne, które w wielu przypadkach stanowiły źródło wiedzy biskupa Hippony o męczennikach. Ponadto omówiona została terminologia martyrologiczna. W kolejnych trzech rozdziałach przedstawione zostały owoce wnikliwych analiz zagadnień martyrologicznych w przemówieniach św. Augustyna. Autor poświęcił drugi rozdział związkowi męczeństwa z osobą Chrystusa, rozdział trzeci - tematyce eklezjologicznej, czyli znaczeniu męczeństwa dla wspólnoty Kościoła, a w czwartym podjął takie tematy teologiczne jak męczeństwo rozumiane jako walka z szatanem, wezwania moralne płynące z postawy męczenników oraz motywy eschatologiczne. Treścią ostatniego rozdziału są, jak już wspomniano, formalne aspekty mów o męczeństwie.

Napodstawie przepowiadaniaśw. Augustyna ks. Seweryn dokonał wnikliwej analizy nie tylko cierpień, jakim poddani byli męczennicy, ale także pokus, zjakimi walczyli. Pierwszą z owych pokus były przyjemności, które obiecywał Szatan, gdy chrześcijanin wyrzeknie się wiary i pozostanie przy życiu. Święty z Hippony uważał, że wielu męczenników było kuszonych błaganiami swoich najbliższych, usiłujących nakłonić ich do ratowania doczesnego życia. Gdy ta pokusa okazała się próżna, Szatan przystępował do bezpośrednich ataków: przez ból i cierpienie starał się zniechęcić męczenników do wierności Chrystusowi, wykorzystując naturalne dążenie człowieka do ochrony własnego zdrowia i życia. Gdy wreszcie za- dawane cierpienia zawodziły, zły duch przychodził z pokusą pychy, by męczennik, doznając męki, przypisał sobie zasługę jej zniesienia. W takim przypadku Szatan zwyciężyłby w duszy takiego człowieka, a więc poniesiona śmierć byłaby daremna.

Autor książki zdołał odpowiedzieć na ważne pytanie, dlaczego św. Augustyn tak wnikliwie analizował pokusy męczenników i apelował o odrzucenie pychy, skoro przemawiał w czasie, gdy krwawe prześladowania chrześcijan były sporadyczne. Otóż takie właśnie podejście do kwestii męczeństwa sprowokowane zostało przez zachowanie heretyków - donatystów, którzy według św. Augustyna ulegali pokusie pychy - szukali chwały, popełniając samobójstwo i nazywając je „męczeństwem”. Cel autora książki był jednak jeszcze szerszy. Chodziło mu bowiem o udzielenie odpowiedzi na pytanie, w jakiej mierze teologia męczeństwa rozwijająca się w IV i V wieku chrześcijaństwa znalazła odbicie w przepowiadaniu biskupa Hippony. Cel ten został osiągnięty, gdyż autor w usystematyzowany sposób przedstawił i omówił martyrologiczne treści w przepowiadaniu św. Augustyna.

Autor ze swobodą pracuje na tekstach źródłowych w języku łacińskim i poddaje je rzetelnej analizie. Nie sposób jednak nie zauważyć, że niektóre z cytatów są wielokrotnie powtarzane w nieco innym kontekście. Imponująca jest wielojęzyczna bibliografia zawierająca opracowania w języku francuskim, niemieckim i włoskim oraz sporadycznie w języku angielskim.

Książka jest napisana językiem naukowym, ale jasnym i zrozumiałym. Cenną pomocą przy lekturze są sporządzone przez autora wprowadzenia do poszczególnych rozdziałów i ich podsumowania. Lektura jest miejscami wręcz pasjonująca, a to głównie za sprawą udostępnienia przez autora książki głębokich i pięknie sformułowa- 
nych myśli św. Augustyna, który był jednym z najwybitniejszych retorów, i to nie tylko w swoich czasach. Przytaczanie myśli tak wspaniałego mówcy i pisarza, którym zachwyca się cały świat - i to nie tylko chrześcijański, bo Augustyn znalazł swoje trwałe miejsce w literaturze powszechnej - sprawia, że wszelkie komentarze do tych myśli bledną. A jednak są one potrzebne. Małodusznością byłoby rezygnować z opracowania ogromnego dorobku kaznodziejskiego wielkiego mówcy z Hippony. Ksiądz Artur Seweryn podjął udaną próbę analizy części tego dorobku.

ks. Henryk Sławiński 